\title{
Biogas Production from Different Substrates under Anaerobic Conditions
}

\author{
Mohamed Yasreen Mohamed $\mathrm{Ali}^{1}$, Marlia Mohd Hanafiah ${ }^{1}$, Yeong Hui Wen ${ }^{1}$, Mushrifah Idris ${ }^{1}$, Nur \\ Izzah Hamna Abdul Aziz ${ }^{1}$, Azhar Abdul Halim ${ }^{1}$ and Khai Ern Lee ${ }^{2}$
}

\begin{abstract}
Biogas technology has become popular in developing countries including Malaysia and it can be used to convert the organic wastes from livestock, human activities, agriculture and industries into manure and green energy. Biophysical characteristics and biogas production from different substrates, i.e goat dungs, chicken dungs, sewage sludge and palm oil mill effluent were analyzed. Anaerobic biogas production of the four substrates was measured using Bio-Methane Potential (BMP) assay in mesophilic condition for 20 days. This study shows that in mesophilic conditions, anaerobic co-digestion from goat dungs using industrial inoculum produced the highest amount of biogas. We found that the traditional bokashi is not suitable as catalyst due to an absence of methane gas. The results from this study suggested that industrial inoculum can potentially increase biogas yield thus methane emissions can be avoided by processing organic wastes-based substrates into biogas.
\end{abstract}

Keywords-Bio-methane Potential, inoculum, methane yield, renewable energy.

\section{INTRODUCTION}

$\mathrm{T}_{\mathrm{s}}^{\mathrm{H}}$ HE use of biogas from organic wastes is a promising alternative for clean and renewable energy production [1]. Producing renewable energy such as biogas can contribute to decreasing dependency on fossil fuels consumption. Biogas consists of methane gas $\left(\mathrm{CH}_{4}\right)$ with a composition of $40 \%$ to $70 \%, 25 \%$ to $40 \%$ carbon dioxide $\left(\mathrm{CO}_{2}\right)$ and other contaminant gases such as hydrogen gas $\left(\mathrm{H}_{2}\right)$, nitrogen and hidrogen sulphide $\left(\mathrm{H}_{2} \mathrm{~S}\right)$. It is a combustible mix of gases produced by the decomposition of organics through the anaerobic digestion. There are four main biological and chemical stages of anaerobic digestion including the process of hydrolysis, acidogenesis, acetogenesis and methanogenesis that can be used to produce biogas from biomass sources [2]. Each stage needs different anaerobic bacteria such as Lactobacillus sp., Clostridium sp., Methanobacter sp., and Aminobacterium sp. to decompose the organic materials to methane gas.

Mohamed Yasreen Mohamed $\mathrm{Ali}^{1}$, Marlia Mohd Hanafiah ${ }^{1}$, Yeong Hui Wen $^{1}$, Mushrifah Idris ${ }^{1}$, Nur Izzah Hamna Abdul Aziz ${ }^{1}$ and Azhar Abdul Halim ${ }^{1}$ are with the School of Environmental and Natural Resource Sciences, Faculty of Science and Technology, Universiti Kebangsaan Malaysia, 43600 UKM Bangi, Selangor, Malaysia

Khai Ern Lee ${ }^{2}$, is with Institute for Environment and Development (LESTARI), Universiti Kebangsaan Malaysia, 43600 UKM Bangi, Selangor, Malaysia
In this study, the biophysical features of the following substrates: goat dungs (GD), chicken dungs (CD), sewage sludge (SS) and palm oil mill effluent (POME) were determined. A comparative study of biogas production from GD, CD, SS and POME was also carried-out using industrial inoculum and traditional bokashi as catalysts.

\section{METHODOLOGY}

\section{A. Sampling Method}

$3 \mathrm{~kg}$ of goat dungs and chicken dungs were collected and were packed in airtight plastic bags to make sure the samples are mixed well. POME was sampled using a liter capacity Schott bottle from the pipe that drained the POME to the treatment ponds. $3 \mathrm{~L}$ of POME was collected in the Schott bottles. Sewage sludge was obtained from the drained pipe connected to the sludge digestion tank containing sewage mixture from primary and secondary clarifications. The sewage sludge was bottled in Schott bottles as well. The initial $\mathrm{pH}$ and temperature of the substrates were recorded. Airtight plastic bags and Schott bottles containing samples were then placed in an airtight container filled with ice-cubes. The inner temperature was set at $4^{\circ} \mathrm{C}$ in order to minimize the bacteria decomposition of the substrates.

\section{B. Experimental/Theoretical Study}

A laboratory analysis was done to determine the biophysical characteristics and Bio-Methane Potential (BMP) assay was used to measure anaerobic biogas production of the four substrates in mesophilic condition for 20 days.

The biophysical characteristics involve analyses of dry mass (DM) and organic dry mass (ODM), organics loading rate (OLR), temperature, $\mathrm{pH}$, chemical oxygen demand (COD), heavy metal analysis, nutrient analysis, AmmoniaNitrogen Test and CHNS analysis.

DM and ODM tests were conducted to determine the percentages of dried solids content and organics dried solids content in the substrates. These percentage values are important to determine the quantity of the substrates required in Bio-Methane Potential Test. DM and ODM percentages (\%) were calculated by:

$$
\begin{aligned}
& \mathrm{DM}=\frac{\text { Dried Sample Weight }}{\text { Wet Sample Weight }} \times 100 \\
& \mathrm{ODM}=\frac{\text { Dry Sample Weight }- \text { Dry Ash Weight }}{\text { Dry Sample Weight }(g)} \times 100
\end{aligned}
$$


OLR was calculated based on the percentages of DM and ODM. The organic loading rate for a liter capacity of digester is $4 \mathrm{~g} / \mathrm{L}$. The quantity of substrates (A) was determined by:

$$
\mathrm{A}=\frac{0.5 \times \mathrm{OLR}\left(\frac{4 \mathrm{~g}}{\mathrm{~L}}\right)}{\text { DM } \times \text { ODM }}
$$

\section{RESUlts AND Discussion}

Table I shows that DM for chicken dungs is $76.78 \%$ higher than other substrates implying that water content or moisture in chicken dungs is lower than other substrates. A high percentage of organic materials affects methane gas productions as $80 \%$ of methane is produced from ODM of substrates. ODM of four substrates is more than $50 \%$ indicating that substrates are able to produce biogas.

TABLE I

PERCENTAGES OF DM AND ODM AND SUBSTRATE

\begin{tabular}{lccc}
\hline \multicolumn{1}{c}{ Substrates } & DM $(\%)$ & ODM $(\%)$ & SQ $(\mathrm{g})$ \\
\hline GD & $63.85 \pm 0.7$ & $85.07 \pm 0.2$ & 3.68 \\
CD & $76.78 \pm 1.5$ & $65.28 \pm 2.3$ & 4.04 \\
POME & $4.17 \pm 0.06$ & $83.88 \pm 1.31$ & 57.70 \\
SS & $6.38 \pm 0.06$ & $76.44 \pm 0.55$ & 41.00 \\
\hline \hline
\end{tabular}

The biophysical characteristics were analyzed including temperature, $\mathrm{pH}$, chemical oxygen demand (COD), heavy metal analysis, nutrient analytical, Ammonia-Nitrogen Test and CHNS analysis and shown in Table II.

TABLE II

BIOPHYSICAL CHARACTERISTICS OF SUBSTRATES

\begin{tabular}{lllll}
\multicolumn{5}{c}{ BIOPHYSICAL CHARACTERISTICS OF SUBSTRATES } \\
\hline \hline \multicolumn{1}{c}{ Parameter } & \multicolumn{1}{c}{ GD } & \multicolumn{1}{c}{ CD } & \multicolumn{1}{c}{ POME } & SS \\
\hline Temperature $\left({ }^{\circ} \mathrm{C}\right)$ & 26.47 & 25.07 & 68 & 49 \\
$\mathrm{pH}$ & 9.78 & 6.87 & 5.60 & 6.70 \\
$\mathrm{COD}(\mathrm{g} / \mathrm{L})$ & $1.93 \pm$ & $2.80 \pm$ & $0.57 \pm$ & $0.33 \pm$ \\
& 0.06 & 0.14 & 0.01 & 0.02 \\
$\mathrm{NH}_{3}-\mathrm{N}(\mathrm{g} / \mathrm{L})$ & 1.30 & 7.30 & 0.42 & 0.31 \\
Carbon, $\mathrm{C}(\mathrm{g} / \mathrm{L})$ & 419.5 & 266.7 & 44.10 & 5.73 \\
Nitrogen, $\mathrm{N}(\mathrm{g} / \mathrm{L})$ & 34.99 & 35.03 & 0.90 & 1.07 \\
\hline \hline
\end{tabular}

The highest ammonia-nitrogen content was found in chicken dungs $(7.30 \mathrm{~g} / \mathrm{L})$, whereas the lowest content was recorded in sewage sludge $(0.31 \mathrm{~g} / \mathrm{L})$. The ammonia concentration between $0.5 \mathrm{~g} / \mathrm{L}$ to $1 \mathrm{~g} / \mathrm{L}$ is beneficial to biogas production and concentration more than $15 \mathrm{~g} / \mathrm{L}$ will retard the biogas production. In the digester bottle, the ammonia concentration shouldbelow $0.8 \mathrm{~g} / \mathrm{L}$ as methanogenic bacteria is sensitive to high ammonia concentration.

Low $\mathrm{C} / \mathrm{N}$ ratio triggers ammonia production and increases $\mathrm{pH}$ value to more than 8.5 and considered harmful to methanogenic bacteria. High $\mathrm{C} / \mathrm{N}$ ratio will decrease methane production due to shortage in nitrogen element which digested by methanogen. The results show that $\mathrm{C} / \mathrm{N}$ ratio for $\mathrm{POME}$ is higher than the ideal $\mathrm{C} / \mathrm{N}$ ratio.

Table III shows the heavy metals and nutrients content of four substrates. The highest Calcium content was found in chicken dungs $(10.50 \mathrm{~g} / \mathrm{L})$ compared to other substrates with less than $1.50 \mathrm{~g} / \mathrm{L}$. Calcium concentration with more than 0.3 $\mathrm{g} / \mathrm{L}$ is beneficial for biogas production and calcium concentration up to $70 \mathrm{~g} / \mathrm{L}$ does not result in any negative impacts on biogas production. The highest $\mathrm{Mg}$ content was recorded for goat dungs with $8.10 \mathrm{~g} / \mathrm{L}$, whereas $\mathrm{Li}$ was undectected in POME and sewage sludge. $\mathrm{Mg}$ shortened the time for substrate to decompose and increased the biogas production if the $\mathrm{Mg}$ content is more than $0.03 \mathrm{~g} / \mathrm{L}$ up to 0.2 $\mathrm{g} / \mathrm{L}$. With the $\mathrm{Mg}$ content more than $10 \mathrm{~g} / \mathrm{L}$, the $\mathrm{Mg}$ will retard the biogas production.

Protein is a combination of amino acids with peptide bonds hydrolysed by proteases. Decomposed amino acid forms ammonia $\left(\mathrm{NH}_{3}\right)$, carbon dioxide $\left(\mathrm{CO}_{2}\right)$ and hydrogen $\left(\mathrm{H}_{2}\right)$. High concentration of protein causes negative effects on biogas production as ammonia concentration increased and retard methanogenic bacteria growth. Table III also shows that ash contents in all substrates are lower than $1 \mathrm{~g} / \mathrm{L}$. For carbohydrates, the highest content was found in goat dungs $(4.73 \mathrm{~g} / \mathrm{L})$. Carbohydrates is the main contributor for biogas production as carbohydrates's structure is made up from carbon $(\mathrm{C})$, hydrogen $(\mathrm{H})$ and oxygen $(\mathrm{O})$ with $\mathrm{H}$ ratio is twice than Carbon and Oxygen. Carbon forms four hydrogen bonds with hydrogen ions to form $\mathrm{CH}_{4}$. Decomposition of fats helps in biogas production as fats is a complex organic which degraded through biogas proceses.

TABLE III

HEAVY METALS AND NUTRIENTS ANALYSIS

\begin{tabular}{|c|c|c|c|c|c|}
\hline \multicolumn{2}{|c|}{ Parameter $(\mathrm{g} / \mathrm{L})$} & \multirow{2}{*}{$\begin{array}{l}\text { GD } \\
1.48\end{array}$} & \multirow{2}{*}{$\begin{array}{l}\text { CD } \\
10.50\end{array}$} & \multirow{2}{*}{$\begin{array}{l}\text { POME } \\
1.36\end{array}$} & \multirow{2}{*}{$\begin{array}{l}\text { SS } \\
1.36\end{array}$} \\
\hline Heavy & $\mathrm{Ca}$ & & & & \\
\hline metal & $\mathrm{Mg}$ & 8.10 & 5.53 & 1.53 & 2.43 \\
\hline & $\mathrm{Li}$ & 0.21 & 0.21 & $u d^{\mathrm{a}}$ & $u d^{\mathrm{a}}$ \\
\hline \multirow[t]{4}{*}{ Nutrient } & Protein & 0.83 & 0.69 & 0.60 & 0.06 \\
\hline & Carbohydrates & 4.73 & 0.51 & 1.90 & 0.06 \\
\hline & Fats & 0.18 & 0.05 & 0.70 & 0.00 \\
\hline & Ash & 0.6 & 0.86 & $-{ }^{b}$ & $-{ }^{b}$ \\
\hline
\end{tabular}

a ud = undetected, ${ }^{\mathrm{b}}-=$ no test conducted.

Fig. 1 shows the percentage of methane gas produced by the four substrates using industrial inoculum. Chicken dungs produce the highest methane gas $(30.2 \%)$, whereas the lowest methane gas production was found for sewage sludge with only $19.5 \%$. This implies that the organic content in chicken dungs is higher compared to sewage sludge. 


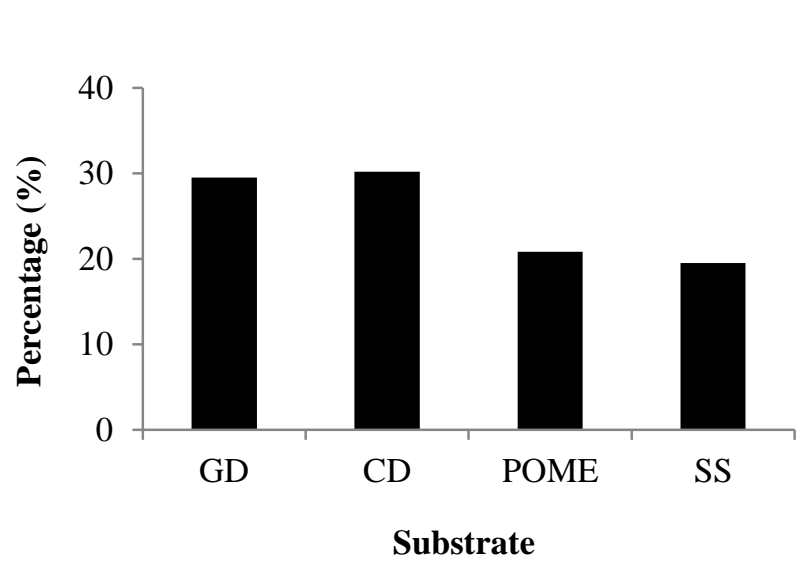

Fig. 1 Percentages of methane gas produced from four substrates using industrial inoculum.

Figs. 2 and 3 show the total biogas production of four substrates using industrial inoculum and traditional bokashi. Using traditional bokashi, the production of biogas from four substrates ranges from $269 \mathrm{~mL}$ to $1135 \mathrm{~mL}$. By using industrial inoculum, the results show that goat dungs produced the greatest amount of biogas $(2141 \mathrm{~mL})$ followed by chicken dungs, POME and sewage sludge with a total biogas production of $1886 \mathrm{~mL}, 744 \mathrm{~mL}$ and $548 \mathrm{~mL}$, respectively.

It was found that industrial inoculum appears to be a better option as catalyst than traditional bokashi since there is no methane gas produced using traditional bokashi. This is due to the fact that concentration of hydrogen sulfide and ammonia gases is high and methanogenic bacteria is unable to grow in acidic medium. Although high amount of $\mathrm{Ca}$ and $\mathrm{Mg}$ were found in sewage sludge, nutrient content of this waste is low, thus producing low amount of biogas.

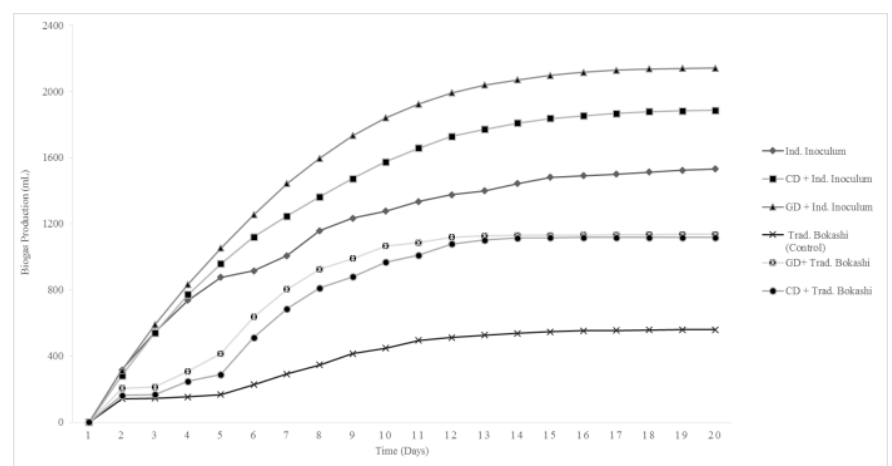

Fig. 2 Biogas production from chicken dungs and goat dungs using industrial inoculum and traditional bokashi

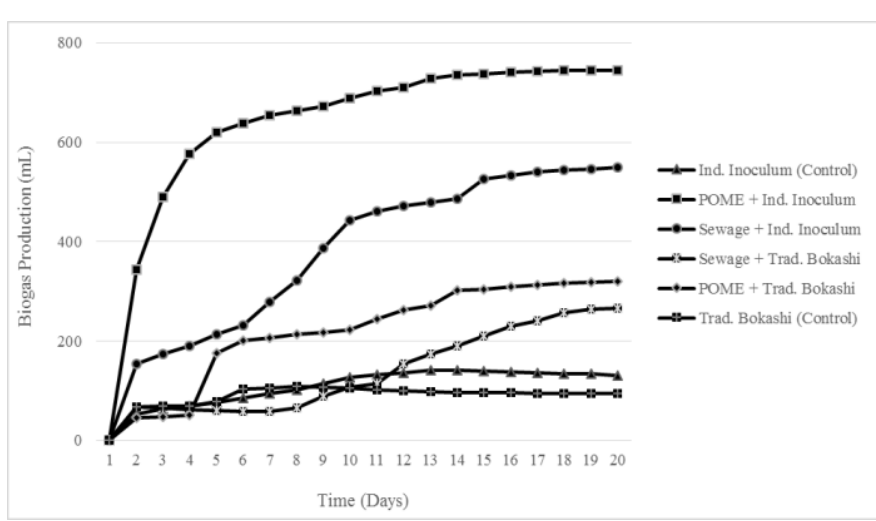

Fig. 3 Biogas production from POME and sewage sludge using industrial inoculum and traditional bokashi

Future study can be done by measuring biogas production using other organic wastes. However, several limitations associated with the biogas production such as lack of process stability, slow recovery after failure, low loading rates and specific requirements for waste composition should be carefully taken into consideration [3]. This is due to the fact that biogas production depends greatly on various factors such as temperature, $\mathrm{pH}, \mathrm{C} / \mathrm{N}$ ratio, etc.

\section{CONCLUSION}

It can be concluded that organic wastes have been seen as a potential solution for reducing environmental impacts of human activities towards sustainable energy source. Furthermore, anaerobic digestion of various organic substrates can provide a better solution of organic waste management in Malaysia by keeping the waste out of the landfill and reducing our dependence on fossil fuel consumption.

\section{ACKNOWLEDGMENT}

We gratefully acknowledge use of the facilities and services provided at the Tasik Chini Research Centre (PPTC), UKM. Marlia Mohd Hanafiah was financed by research grants from the Universiti Kebangsaan Malaysia (UKM) and the Ministry of Higher Education Malaysia research grants (DLP-2013034 and FRGS/2/2013/STWN01/UKM/03/1).

\section{REFERENCES}

[1] G. Alkanok, B. Demirel, and T. T. Onay, "Determination of biogas generation potential as a renewable energy source from supermarket wastes," Waste Management, vol. 34, no. 1, pp. 134-140, 2014. http://dx.doi.org/10.1016/j.wasman.2013.09.015

[2] Yadvika, Santosh, T. R. Sreekrishnan, S. Kohli, and V. Rana, "Enhancement of biogas production from solid substrates using different techniques - a Review," Bioresource Technology, vol. 95, no. 1, pp. 1-10, 2004.

http://dx.doi.org/10.1016/j.biortech.2004.02.010

[3] L. Van der Berg, and K. J. Kennedy, "Comparison of advanced anaerobic reactors," in Proc. of III International Conference on Anaerobic digestion, Boston, 1983. 